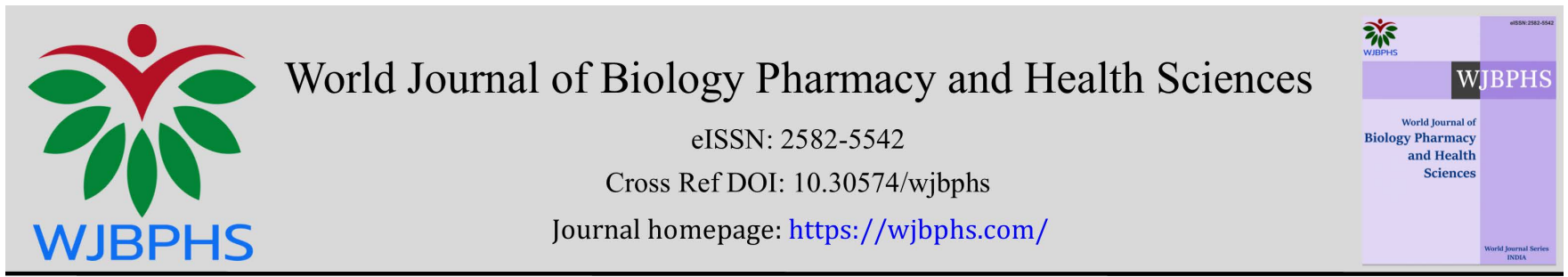

(RESEARCH ARTiCLE)

\title{
Effects of aqueous leaf extract of Corchorus olitorius on sperm count and sperm motility of adult wistar rats
}

\author{
Godwin Chinedu Uloneme * \\ Department of Anatomy \& Neurobiology, Faculty of Basic Medical Sciences, Imo State University, Owerri, Nigeria.
}

World Journal of Biology Pharmacy and Health Sciences, 2021, 06(02), 001-006

Publication history: Received on 08 March 2021; revised on 13 April 2021; accepted on 21April 2021

Article DOI: https://doi.org/10.30574/wjbphs.2021.6.2.0032

\begin{abstract}
Background: The plant, Corchorus olitorius is consumed by many tribes and cultures for both nutritional and therapeutic purposes.

Purpose: The study was therefore designed to investigate, evaluate and unravel the possible effects of the plant extract on the sperm count and sperm motility.

Method: A total number of thirty two adult Wistar rats weighing between 180 and 200 g separated into four groups labeled A,B,C and D respectively were used for the study. Animals in group A which served as the control group were fed with the normal rat chow and water only. The group B rats were administered $100 \mathrm{mg} / \mathrm{kg}$ body weight of aqueous extract of Corchorus olitorius; while those in group C were administered $500 \mathrm{mg} / \mathrm{kg}$ body weight of the extract. The group D rats received $1000 \mathrm{mg} / \mathrm{kg}$ body weight of the extract. For a period of four weeks, the different experimental animal groups received the respective aforementioned treatments once daily, around nine- o'clock in the morning through oral intubation.

At the end of the 28 day treatment, the rats were sacrificed and the testes and accompanying epididymis harvested for investigations using standard laboratory standards.

Results: Surprisingly, semen analysis showed that group B, C and D rats had an improved and increased sperm motility rate over group (A). Again, there was a pronounced significant increase in the average sperm count of the rats treated with varying doses of Corchorus olitorius leaf extract over that of the control group, a development that appeared to be dose dependent.
\end{abstract}

Keywords: Corchorus olitorius; Epididymis; Sperm count; Sperm motility; Testis; Wistar rats

\section{Introduction}

The plant, Corchorus olitorius, widely grown in the tropics belongs to the family of Tiliaceae, and according to Matsufuji et al, (2001) [1]. It has a high content of vitamin A and C, calcium, iron and fibre. In the Yoruba tribe of Nigeria, where it is called Ewedu, the leaves are used to prepare fresh soup and stew both in fresh and dried form Tindall, (1983) [2].

Oke (1968) [3] in his analysis, stated that the plant on average, contains 1-5mg fibre, 4-8mg Fe, 250-266mg Ca, 0.3mg riboflavin, $0.1 \mathrm{mg}$ thiamine, and about $5 \mathrm{~g}$ carbohydrate. According to Ndlovu and Afolayan (2008) [4], the roots and leaves of corchorius olitorius are eaten as herbal medicine in South East Asia. In Nigeria and some other West African

${ }^{*}$ Corresponding author: Godwin Chinedu Uloneme

Department of Anatomy \& Neurobiology, Faculty of Basic Medical Sciences, Imo State University, Owerri, Nigeria.

Copyright (C) 2021 Author(s) retain the copyright of this article. This article is published under the terms of the Creative Commons Attribution Liscense 4.0. 
countries, the leaves which are mucilaginous are used as food vegetables Zakaria et al, (2006) [5] aimed at treating iron and folic acid deficiency. Aiyeloja and Bello (2006) [6] had reported that the leaves act as blood purifier. The leaf twigs are also believed to possess healing effects against heart problems Amany and Nabila, (2015) [7]. In their work, Ebeye and Ekundina (2015) [8] asserted that the plant products are demulcent, exhibiting rapid soothing effects, galactagogue in action, deobstruent, diuretic and antipyretic. The aqueous extract of corchorius olitorius has also been demonstrated to posses Opioid-mediated anti-nociceptive action Zakari et al, (2005) [9]. Gupta et al (2003) [10] reported that the methanolic extract of the plant has anti-convulsive property, while its leaf extract has been shown to reduce elevation of postprandial blood glucose levels in both rats and humans (Innami et al, 2005)

From the aforegoing, it could be understood that there is a pronounced indiscriminate and high consumption rate of the plant products, especially the leaves for several purposes ranging from therapeusis to curative activities, and most largely for dietetic and nutritional reasons. As a matter of fact, there is at present, very little information on the effect of corchorius olitorius on the male gonad, where gamatogenesis takes place, neither is there at hand much information on the effect of the plant on the sperm count and sperm motility believed to be very important parameters in the determination of the fertility status of an individual, a reason why fertility friendly plant products that improve sperm count and sperm motility should be identified and made public for consumption by the generality of the people.

\section{Material and methods}

\subsection{Experimental Animals}

Thirty two adult wistar rats weighing between 180 and $200 \mathrm{~g}$ bred in the animal house of Anatomy \& Neurobiology Department, Faculty of Basic Medical Science, Imo State University, Owerri were used for this study. The rats were separated into four groups and housed in four separate cages marked A, B, C, and D respectively. The group A rats constituted the control group, while group B, C, and D formed the experimental groups. The rats were made to have free access to feed and water before and during the experimentation that lasted for twenty eight (28) days.

\subsection{Preparation of Leaf Extract}

About two weeks before housing the rats in separate cages for the experimentation proper, fresh leaves of Corchorus olitorius were harvested from a local farm and air-dried. The dried leaves were then ground into powdered form. The powder was then macerated in distilled water in 1:2wt/vol ratio and hours later, the filtrate was dried into a gel-like form with an oven and stored in readiness for administration to the rats.

\subsection{Administration of Extract}

The group B rats were administered $100 \mathrm{mg} / \mathrm{kg}$ body weight $(0.8 \mathrm{ml})$ of Corchorus olitorius of the aqueous extract. The groups $\mathrm{C}$ and $\mathrm{D}$ rats received $100 \mathrm{mg} / \mathrm{kg}$ body weight $(1.8 \mathrm{mls})$ and $1000 \mathrm{mg} / \mathrm{kg}$ body weight $(2.8 \mathrm{mls})$ of the extract respectively, all through oral intubation.

Group A (control) received only water and normal rat chow.

\subsection{Collection of sample}

At the end of the twenty eight day treatment, the different animal groups were anaesthetized using chloroform vapour.

\subsection{Semen Collection}

The testis together with the epdidymides were excised. The distal epididymides were then cut open to expose the semen for collection by applying a little pressure on the caudal epididymis to squeeze the semen into a microscope slide. Two drops of $2.9 \%$ sodium citrate was added and the slide was covered with a cover slip for examination and evaluation under the microscope. The sperm cells under investigation were labeled as non-motile, sluggish or actively motile. The percentage of motile sperm cells was calculated by dividing the number of motile sperm cells by the total number of counted sperm cells Osuchukwu (2016) [11]. The sperm count was then carried out using the Neubauer Haemocytometer.

\subsection{Statistical Analysis}

The data generated from the study was analyzed using the standard package for social sciences computer software (SPSS), and using the T-test and the one-way analysis of variance (ANOVA), the tested parameters were subjected to statistical analysis. $\mathrm{P} \leq 0.05$ was considered significant. 


\section{Results}

Table 1 Effect of Aqueous leaf extract of Corchorus olitorius on active sperm motility.

\begin{tabular}{|l|l|l|l|l|}
\hline \multirow{2}{*}{ Group } & \multicolumn{2}{l|}{ Active Motility \% } & \multirow{2}{*}{ P value } & \multirow{2}{*}{ F value } \\
\cline { 2 - 3 } & MEAN & \pm SEM & & \\
\hline Group A & 79.00 & \pm 3.13 & 0.000 & \\
\hline Group B & 89.00 & \pm 3.22 & 0.000 & \\
\hline Group C & 93.00 & \pm 2.90 & 0.000 & 89.00 \\
\hline Group D & 97.33 & \pm 1.75 & 0.000 & \\
\hline
\end{tabular}

The result table1 shows that there was a defined significant increase in active motility of sperm cells of group B rats over the control group. Same applies for group C rats in which the active sperm motility was rated higher than B. ultimately, the active motility rate of group D superseded that of group C. The progression ratio order (in percentage) is: Group A $(79 \pm 3.13)$ : B $(89.00 \pm 3.22)$ : C $(93.00 \pm 2.90)$ : D $(97.33 \pm 1.7$

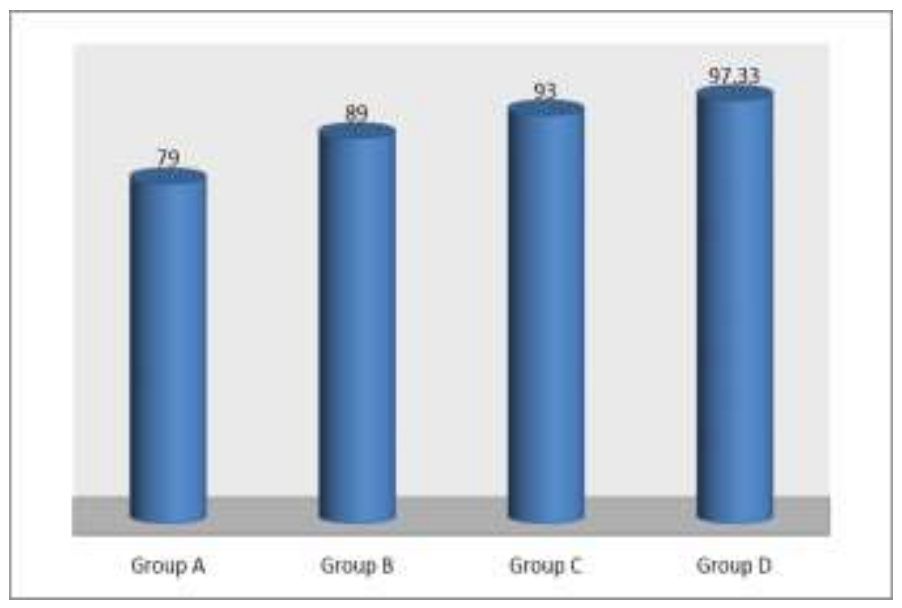

Figure 1Eeffect of aqueous leaf extract of Corchorus olitorius on active sperm motility.

Table 2 Effects of Aqueous leaf extract of Corchorus olitorius on sluggish sperm motility.

\begin{tabular}{|l|l|l|l|l|}
\hline \multirow{2}{*}{ Group } & \multicolumn{2}{|l|}{ Sluggish Motility \% } & \multirow{2}{*}{ P value } & \multirow{2}{*}{ F value } \\
\cline { 2 - 3 } & MEAN & \pm SEM & & \\
\hline Group A & 14.34 & \pm 2.00 & 0.000 & \\
\hline Group B & 8.78 & \pm 2.00 & 0.000 & \\
\hline Group C & 4.93 & \pm 2.78 & 0.000 & 188.8 \\
\hline Group D & 2.96 & \pm 2.00 & 0.000 & \\
\hline
\end{tabular}

The result from table 2 shows that there was a marked decrease in the sluggish motility of the Group B, C and D sperm cell when compared to the control group (A) respectively. 


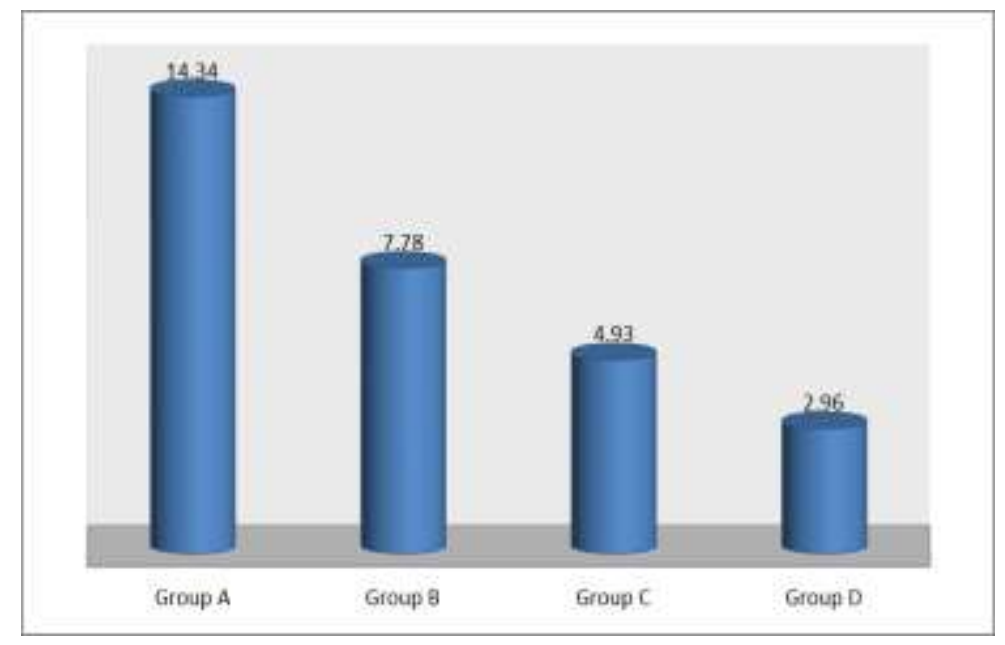

Figure 2 Effect of aqueous leaf extract of Corchorus olitorius on sluggish sperm motility.

Table 3 Effects of aqueous leaf extract of Corchorus olitorius on total sperm count.

\begin{tabular}{|l|l|l|l|l|}
\hline \multirow{2}{*}{ Group } & \multicolumn{2}{|l|}{ Total Sperm count \% } & \multirow{2}{*}{ P value } & \multirow{2}{*}{ F value } \\
\cline { 2 - 3 } & MEAN & \pm SEM & & \\
\hline Group A & 6.80 & \pm 0.47 & 0.000 & \\
\hline Group B & 8.90 & \pm 0.43 & 0.000 & \\
\hline Group C & 10.00 & \pm 2.88 & 0.000 & 63.31 \\
\hline Group D & 39.00 & \pm 1.22 & 0.000 & \\
\hline
\end{tabular}

The result from table 3 shows that there was a significant increase in the average total sperm count of the rats treated with varying doses Corchorus olitorius leaf extract over the control group of rats.

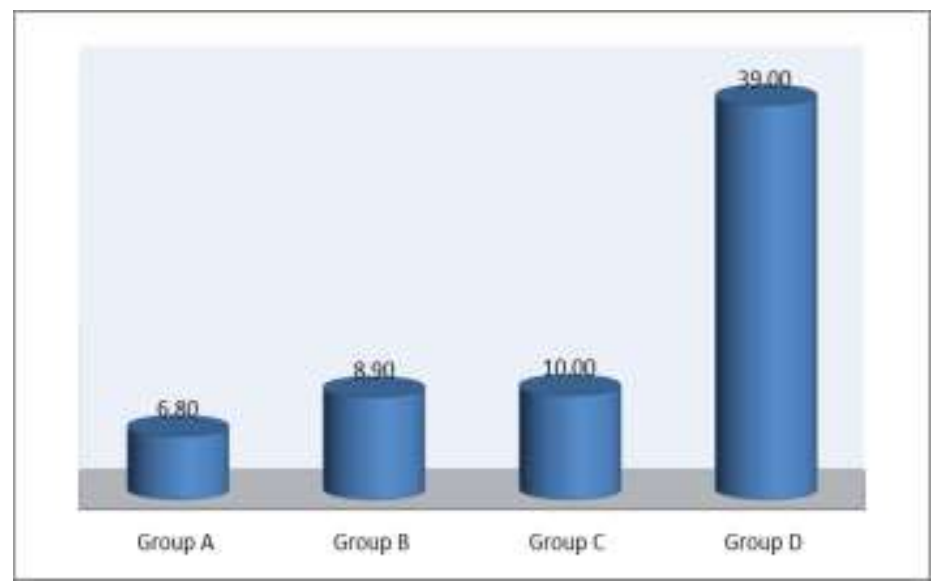

Figure 3 Effect of aqueous leaf extract of Corchorus olitorius on total sperm count.

\section{Discussion}

The semen analysis shows there was significant increase in active motility in all the groups treated with varying doses of aqueous leaf extract of Corchorus olitorius over the control group of rats. It could be assumed that the same factors that promote spermatogenesis and improved sperm count, such as normal plasma testosterone level achieved by consumption of the aqueous extract of the plant leaves may have enhanced the motility rate of the spermatozoa, Reddy 
and Pushpalatha, (2006) [12]. The increment pattern was observed to be dose-dependent and agrees with the finding of Osuchukwu et al (2016) [11]. Conversely, there was a significant decrease in the sluggish motility of the sperm cells in a manner that the sluggish motility rate was inversely proportional to the concentration/dose administered: while the percentage sperm sluggish rate of group A was $14.34 \pm 2.00$, that of group B was $8.78 \pm 2.00$. In the same retrogressive order, the percentage sperm sluggish motility rate of group $C$ was $4.93 \pm 2.78$ as against the $2.96 \pm 2.00$ calculated for group D. this means that sperm sluggish motility conditions could be addressed and ameliorated by consumption of Corchorus olitorius leaves as food components as practiced by the Yoruba tribe of Nigeria. The mechanism of action of the product to bring about this effect is poorly understood, but may not be unconnected with its effect on synthesis and secretion of testosterone which enhances spermatogenesis, improves sperm count and sperm motility Oyedeji et al, (2013) [13] . It could also be as a result of increased blood flow to the testis occasioned by vasodilatation of its vessels, leading to improved spermatogenesis and sperm motility. The conspicuous increase in sperm count observed to be directly dose dependent is of great essence for deeper pharmacological investigations. The group D rats' average sperm count value $(39 \times 106)$ was about six times higher than that of the control, $(6 \times 106)$. This means that higher doses of the extract could be useful in the treatment of oligospermia and possibly other male fertility problems.

\section{Conclusion}

The aqueous leaf extract of Corchorus olitorius has pharmacological potentials to improve sperm count and sperm motility in adult wistar rats, a function necessary for a healthy fertility status.

\section{Compliance with ethical standards}

\section{Acknowledgments}

We sincerely acknowledge the contributions of Mr Sam Offor, the faculty animal house keeper, for the good hygiene in handling of the animals. Mr Shettima, Adamu P. is also acknowledged for typing and editing of the work.

\section{Disclosure of conflict of interest}

No conflict of interest, soul authorship.

\section{Statement of ethical approval}

All procedures involved in the handling and sacrificing of the animals conform to the ethical standards and regulations approved by the university animal research committee.

\section{References}

[1] Matsufuji H, Sakai S, Chino M, Goda Y. (2001). Relationship between cardiac glycoside contents and color of Corchorus olitorius seeds. Journal of Health Sciences. 47 (2): 89-93.

[2] Tindall HD. (1983). Vegetables in the tropics. London: Macmillan press. pp 325-379.

[3] Oke OI. (1968). Chemical changes in some Nigerian vegetables during growth. Experimental Agriculture. 4:345349.

[4] Ndlovu J, Afolayan AJ. (2008). Nutritional analysis of the South African Wild VegetableCorchorus olitorius L. Asian Journal of Plant Science. 7(6):615-618.

[5] Zakaria ZA, Somchit MN, Zaiton H, Mat-Jais AM, Suleiman MR, Farah W, Nazaratul and mawarina (2006). The invitro antibacterial activity of Corchorous olitorius extracts. International Journal of Pharmacology. 2(2):213215.

[6] Aiyeloja AA, Bello OA. Ethnobotanical potentials of common herbs in Nigeria: A case study of Enugu state. Educ. Res. Rev. 2006; 1(1):16-22.

[7] Amany Ramah, Ragab M, EL-shwarby, Nabila MA, Elham A, El-shewey. The Effect of Lead Toxicity on Male Albino Rats Reproduction with Ameliorate by Vitamin E and Pumpkin Seeds Oil. Benha Veterinary Medical Journal. $2015 ; 28(1): 43-52$. 
[8] Ebeye OA, Ekundina VO, Ekele CM, Eboh DEO. The Histological Effect Of Cnidoscolus Aconitifolius Aqueous Leaf Extracts on the Archetecture of the Ovary,Testis and Sperm Cells of Adult Wistar Rats.International Journal of Herbs and Pharmacological Research. 2015; 4(1): 7-17.

[9] Zakari ZA, Safarul R, Fatimah CA. Influence of temperature on the opoid-mediated antinoceptive activity of Corchorus olitorius in mice. Arch. Pharmacol. 2005; 372:55-62.

[10] Gupta M, Mazumder UK, Pal D, Bhattacharya S, Chakrabarty S. (2003). Studies on brain biogenic amines in methanolic extract of Cuscuta reflexa and Corchorus olitorius seed treated mice. Acta. Pol Pharm, 60:207-210.

[11] Osuchukwu IW, Sakpa CL, Ekezie J, Okeke CU, Eke CC, Ezejindu DN. Effect of Leave Extract of Jatropha Tanjorensis on the Testis of Wistar Rats.Journal of Dental and Medical Sciences. 2016; 15(4):66-71.

[12] Reddy PS, Pushpalatha T, Reddy PS. Reduction of spermatogenesis and steroidogenesis in mice after fentin and fenbutatin administration. Toxicol. Lett. 2006; 166: 53 - 59

[13] Oyedeji KO, Bolarinwa AF, Akinbode AA. Effect of Corchorus olitorius Extract on Reproductive Functions in Male Albino Rats.International Journal of Pharmacy and Pharmaceutical Sciences. 2013; 5(3): 427-431. 